\title{
Enforcement and Lawsuit Trends in Intellectual Property Rights in India
}

\author{
Yaeko MITSUMORI ${ }^{*}$ \\ ${ }^{a}$ Center for the Study of Higher Education and Global Admissions, Osaka University, 1-1, Yamadaoka, Suita, Osaka, \\ 565-0871 Japan
}

\begin{abstract}
The Indian government amended its patent act in 2005 and introduced product patents to comply with the TRIPS Agreement. Nevertheless, due to a special provision, they refused a patent for Novartis' Gleevec and issued a compulsory license for a cancer drug by Bayer to a domestic generic drug manufacturer, thus leaving developed countries with the impression that intellectual property may not necessarily be well-protected in India. Meanwhile, the number of patent applications began to increase, as did the number of intellectual property lawsuits; however, due to the aforementioned cases, the general impression is that, often, their courts rule against foreign-affiliated companies, which tend to have many patents. In a recent paper, however, an Indian lawyer indicated that the courts do not always necessarily rule against patent holders. The aim of this study is to examine the present state of intellectual property rights infringement lawsuits in India. In India, not all of the detailed data of lawsuits are made public and thus, it cannot be known whether the number of rulings that favor patent holders is actually increasing, although it has been confirmed that the High Court of Delhi has given at least several rulings in favor of patent holders in recent years.
\end{abstract}

Keywords: Intellectual Property Right, Developing Countries, Pharmaceutical Industry, WTO/TRIPS, India

\section{Introduction}

Advanced countries and foreign pharmaceutical companies tend to have an impression that intellectual property (IP) enforcement in India is quite weak. There have been some landmark events: In March 2012, the Indian Patent Office granted a compulsory license to Natco, an Indian generic pharmaceutical company, for German pharmaceutical company Bayer's anticancer drug, sorafenib (brand name: Nexavar). On April 1, 2013, the Supreme Court of India dismissed Switzerland pharmaceutical company Novartis' patent application covering the active agent of the blockbuster anti-cancer drug Gleevec.

These two events gave foreign capital companies strong messages: Even if a foreign capital pharmaceutical company finds their IP right is infringed by an Indian firm and brings the case to an Indian court, they tend to lose.

However, one study conducted by a lawyer at the Delhi High Court found that Indian courts recently granted a series of judgments that were more favorable for "innovator companies" (i.e., foreign capital companies) than non-innovator companies (i.e., Indian companies).

To examine the current status of IP enforcement in India and determine whether foreign capitals are, indeed, winning in recent court cases in India, this study carried out a documentary analysis as well as a series of on-site interviews with stake holders in India.

\footnotetext{
*Corresponding author: dt4y-mtmr@asahi-net.or.jp
}

\section{Indian Economic Situation}

Whereas most newly industrializing countries have experienced sluggish economic growth over the past several years, India has experienced rapid economic growth. Table 1 shows India's basic economic indicators compiled by JETRO [1].

Table 1 India's basic economic indicators

\begin{tabular}{|c|c|c|c|}
\hline Indicators & 2015 & 2016 & 2017 \\
\hline $\begin{array}{c}\text { Real GDP Growth } \\
\text { Rate }\end{array}$ & $8.2(\%)$ & $7.1(\%)$ & $6.7(\%)$ \\
\hline Nominal GDP & $\begin{array}{l}113,810 \text { (INR } \\
\text { bil) }\end{array}$ & $\begin{array}{l}121,898 \text { (INR } \\
\text { bil) }\end{array}$ & $\begin{array}{l}\text { 130,108（INR } \\
\text { bil） }\end{array}$ \\
\hline $\begin{array}{c}\text { Per Capita Nominal } \\
\text { GDP }\end{array}$ & 1,639 (USD) & 1,749 (USD) & 1,983 (USD) \\
\hline Industrial Index & $3.3(\%)$ & $4.6(\%)$ & $4.3(\%)$ \\
\hline CPI Growth Rate & $4.9(\%)$ & $4.5(\%)$ & $3.6(\%)$ \\
\hline Unemployment rate & $3.5(\%)$ & $3.5(\%)$ & $3.5(\%)$ \\
\hline Exports & $\begin{array}{l}262,290 \text { (USD } \\
\text { mil) }\end{array}$ & $\begin{array}{l}276,238 \text { (USD } \\
\text { mil) }\end{array}$ & $\begin{array}{l}301,854 \text { (USD } \\
\text { mil) }\end{array}$ \\
\hline Imports & $\begin{array}{l}381,007 \text { (USD } \\
\mathrm{mil})\end{array}$ & $\begin{array}{l}382,681 \text { (USD } \\
\text { mil) }\end{array}$ & $\begin{array}{l}461,874 \text { (USD } \\
\mathrm{mil})\end{array}$ \\
\hline
\end{tabular}

Source: JETRO Basic Economic Indicators

The International Monetary Fund (IMF) indicates that implementation of several recent noteworthy policies, such as the enactment of the goods and services tax 
(GST) and the country opening up more to foreign investors. IMF expected Indian economic growth to pick up from $6.7 \%$ in fiscal $2017 / 2018$, to about $7.3 \%$ for fiscal year 2018/19 [2].

The World Bank in India also predicted that India is expected to grow at well over 7\% per year over the next few years, with progress being buttressed by dynamic reforms in the macroeconomic, fiscal, tax, and business environments [3].

\section{Indian Pharmaceutical Industry}

\subsection{Production}

Just after India became independent from Britain in 1947, the pharmaceutical industry in India began to emerge. However, the Indian pharmaceutical industry did not start rapidly growing until the 1970s.

Table 2 shows the growth of the Indian pharmaceutical industry between 1950 and 2001 [4].

Table 2 Development of Indian pharmaceutical industry

\begin{tabular}{|l|r|r|r|r|r|r|}
\hline & $1950-51$ & $1960-61$ & $1970-71$ & $1980-81$ & $1990-91$ & $2000-2001$ \\
\hline manufacturers (No) & 200 & & 2300 & 6400 & 16000 & 20000 \\
\hline Investment (Rs. Mil) & 50 & 560 & 2250 & 6000 & 9500 & 30000 \\
\hline R\&D Expenditure (Rs. Mil) & & & 100 & 290 & 800 & 4000 \\
\hline Production (Rs. Mil) & 100 & 1130 & 4000 & 14400 & 45700 & 228870 \\
\hline Export (Rs. Mil) & & 16 & 85 & 463 & 7848 & 87290 \\
\hline Import (Rs. Mil) & & 176 & 243 & 968 & 4075 & 29800 \\
\hline
\end{tabular}

Source: HR Bhojwani, "Developing Innovative Capacity in India to Meet the Health Needs" Govt. of India (Feb 2005), 7

In 2016, the Indian pharmaceutical industry reached $\$ 27.57$ billion and is expected to grow to $\$ 55$ billion by 2020 [5]. Currently, the Indian pharmaceutical industry is ranked third in the world in terms of volume and fourteenth in terms of value [5].

\subsection{Segment}

Although its economy has been rapidly expanding recently, India is still a developing country. Like many other developing countries, generic drugs occupy the majority of its pharmaceutical market.

According to IBEF Pharmaceuticals, $70 \%$ of the Indian market is occupied by generic drugs (off-patent drugs), with brand-name drugs (patented drugs) occupying merely $9 \%$ of the market [6]. The remainder of the market, $21 \%$, includes over-the-counter (OTC) drugs (see Fig. 1).

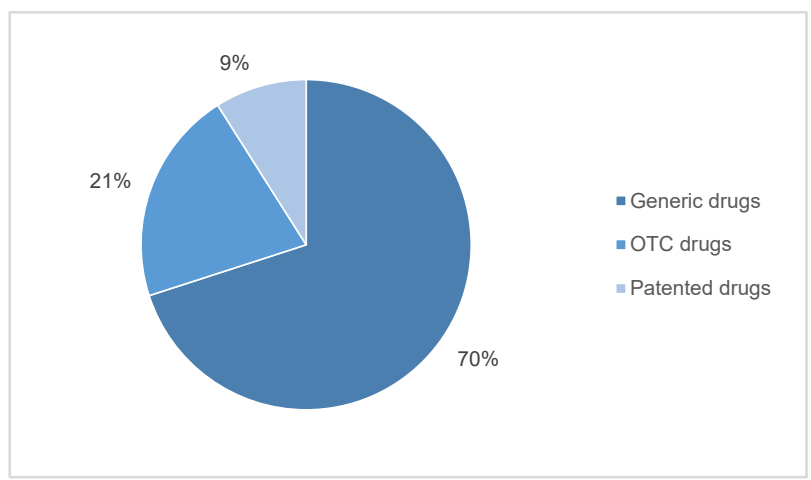

Figure 1 Indian pharmaceutical market by segment Source: IBEF Pharmaceuticals Dec. 2017

\subsection{Disease Profile}

If the disease profile is analyzed, the major diseases in India are so-called acute diseases, such as infectious diseases or injuries [7].

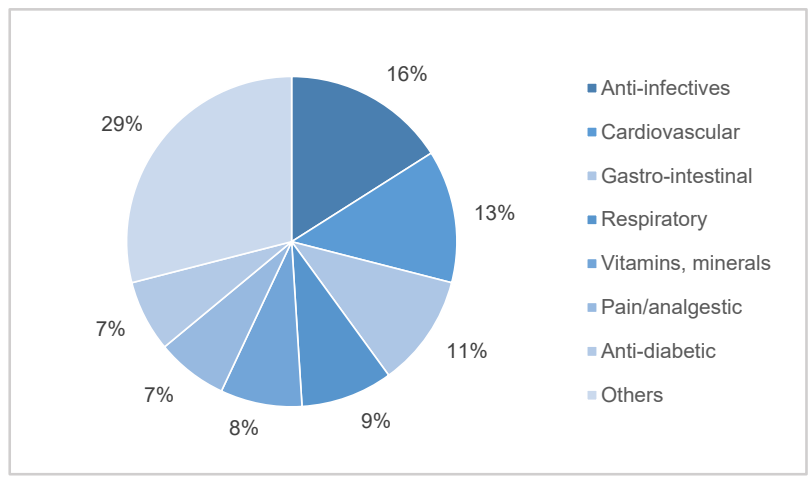

Figure 2 Indian disease profile Source: IBEF Pharmaceuticals, Dec. 2017

One recent trend regarding disease profiles in India is the rapid increase in lifestyle diseases, including cardiovascular disease, diabetes, hypertension, asthma, and respiratory diseases, as well as cancers [8].

Diabetes is especially prevalent in India. According to the International Diabetes Federation [9], there were 72.9 million diabetes patients in India in 2015 - the second highest amount in the world - and the number is expected to increase in the future.

\subsection{Major Indian Companies}

The Indian pharmaceutical market is extremely diversified, with 20,000 pharmaceutical companies located in the country [10].

However, there are only a handful of large players in the Indian pharmaceutical industry, which include Sun Pharmaceuticals, Dr. Reddy's, Lupin, Cipla, and Cadila. Table 3 shows the top 10 pharmaceutical companies in India [11]. 
Table 3 Top 10 Indian pharmaceutical companies

\begin{tabular}{|r|l|r|}
\hline rank & company & revenues (mil \$) \\
\hline 1 & Sun & 3415 \\
\hline 2 & Dr. Reddy's & 2331 \\
\hline 3 & Lupin & 1981 \\
\hline 4 & Cipla & 1787 \\
\hline 5 & Cadila & 1346 \\
\hline 6 & Aurobindo & 1262 \\
\hline 7 & Glenmark & 1024 \\
\hline 8 & Jubilant & 912 \\
\hline 9 & Torrent & 728 \\
\hline 10 & Wockhardt & 720 \\
\hline & Total & 15506 \\
\hline
\end{tabular}

Source: The Indian Pharmaceutical Market_Leading Domestic Companies. GMR Data (2015)

\section{Transition of Patent Law in India}

India, a former British colony, has a long history of patent protection.

Even before the country won independence from Britain, it set up the Indian Patents and Designs Act, 1911 (Act II of 1911). The law protected both product patents and process patents. Under the Indira Gandhi government in the 1970s, India passed the Patents Act, 1970. The act protects process patents but not product patents [12].

However, because India was one of the signatory countries of the World Trade Organization (WTO), it was required to modify its patent system into a TRIPS (The Agreement on Trade-Related Aspects of Intellectual Property Rights) compatible one. After the 10-year grace period (five years were given for developing countries and another five years were given for countries that did not have product patents at the time of the TRIPS enforcement), India modified its patent system and introduced product patents in $2005[13,14]$.

The Patents (Amendment) Act, 2005, was meant to be a TRIPS-compatible, international patent law. However, it has a unique, safe-guarding clause, called Section 3(d), which is as follows:

Section 3(d): the mere discovery of a new form of a known substance which does not result in the enhancement of the known efficacy of that substance or the mere discovery of any new property or new use for a known substance or of the mere new use of a known process, machine or apparatus unless such known process results in a new product or employs at least one new reactant.

Explanation: For the purposes of this clause, salts, esters, ethers, polymorphs, metabolites, pure form, particle size, isomers, mixtures of isomers, complexes, combinations, and other derivatives of known substance shall be considered to be the same substance, unless they differ significantly in properties with regard to efficacy.

Section 3(d) indicates that it will admit patentability when the molecule (the subject for the patent application) is a new chemical entity (NCE) without argument. However, if the molecule is a known substance, it will admit patentability only when it shows enhancement of the known efficacy. The section does not define, however, the kind/type of efficacy.

\section{Judicial System in India}

India has a government in which the administrative, legislative, and judicial powers are separated, called "Separation of Powers." [15].

The Indian court system employs a "three-tiered judicial system": the Supreme Court at the top, followed by High Courts and District Courts. There are 24 High Courts in India, which are responsible for matters in each state and, under each High Court, there are District Courts, one in each district [16].

In the area of intellectual property, Delhi High Court takes an important role. According to Imaura, former director of the IP division of JETRO New Delhi, the Delhi High Court deals with $70 \%$ of the IP-related cases in India. This is because it retains numerous judges who have deep knowledge in IP and significant experience dealing with related cases [17].

\section{Trend of Patent Applications and Grantings}

Taking advantage of the TRIPS agreement in 1995 and the introduction of product patents in 2005, the number of patent applications in India has been rapidly increasing. According to Indian Patent Office annual reports, the number of patent applications in India was 3,869 in FY1993, which grew to 42,763 in FY2014 [18].

Figures 3 and 4 show drug-related patent applications and grantings in India $[19,20]$.

Prior to the introduction of product patents in 2005, the Indian government set up a mailbox in 1999 following the TRIPS requirement and started accepting product patent applications. The mailbox was opened in 2005, and the Indian Patent Office started examining the applications [21].

Reflecting the new procedure, the number of patent applications rapidly increased from 1999 to its peak in 2007 and has gradually decreased since then (see Fig. 3). 


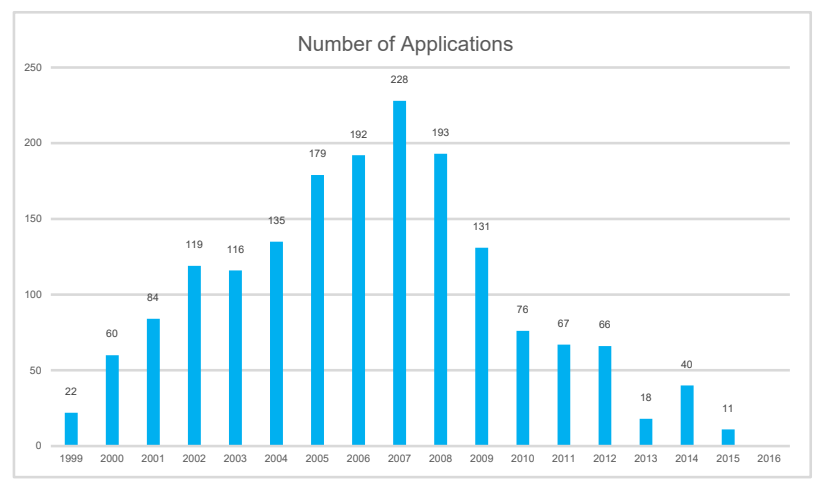

Figure 3 Number of patent applications in India from 1999 to 2015

Source: IQVIA

Following this trend, the number of patents granted was high between 2007 and 2009. Since then, the number has rapidly dropped (see Fig. 4).

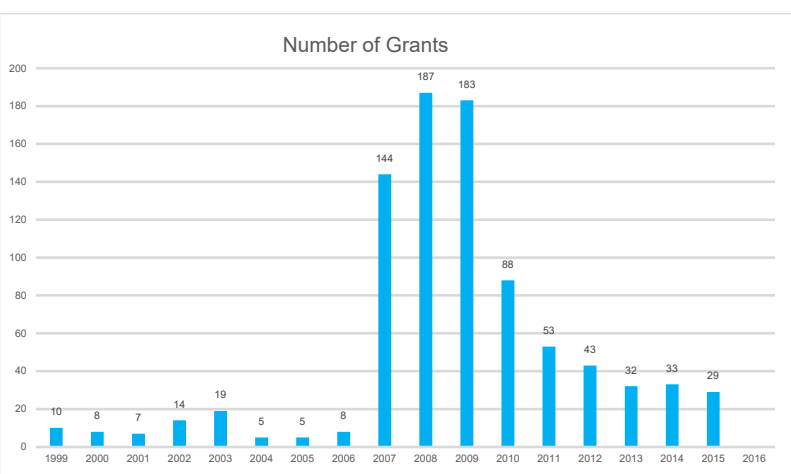

Figure 4 Number of patents granted in India from 1999 to 2015

Source: IQVIA

\section{Landmark IP Cases}

As previously mentioned, there were some landmark judgments in IP/pharmaceutical cases. This section highlights two remarkable cases: Novartis' Gleevec litigation case and the compulsory license granted to Natco.

\subsection{Patent Rejection Case for Novartis' Gleevec}

Novartis filed a patent application in the Chennai (Madras) Patent Office in 1997. On November 10, 2003, Novartis obtained an exclusive market right (EMR) for Gleevec in India. On January 25, 2006, however, the patent office in Chennai refused to grant a patent for Gleevec to Novartis. Novartis, unsatisfied with the rejection, filed a written petition against the government of India and the opponents before the Madras High Court.

On August 2007, the Madras High Court dismissed Novartis' written petition and declared that Section 3(d) was valid. The second appeal regarding the patent rejection was transferred to the Intellectual Property Appellate Board (IPAB), which judged on June 29, 2009, that Novartis' alleged invention did not satisfy the test of Section 3(d).

Novartis then brought the case to the Supreme Court of India. However, on April 1, 2013, it dismissed Novartis' claim $[22,23,24]$.

\subsection{Compulsory License: Bayer vs. Natco}

This case was the first time a compulsory license was issued by the Indian Patent Office.

German pharmaceutical firm Bayer was granted a patent for Sorafenib (brand name: Nexavar) on March 3, 2008, from the Indian Patent Office. Nexavar is a drug for renal cell carcinoma (RCC) and hepato-cellular carcinoma (HCC).

Natco, an Indian pharmaceutical company, approached Bayer on December 6, 2010, seeking for a grant of a voluntary license, which Bayer refused. On July 28, 2011, Natco submitted an application for a compulsory license for Bayer's Nexavar to the Indian Patent Office under Section 84(1) of the Patent (Amendment) Act, 2005. After careful examination, Controller General of Patent and Design Shri P.H. Kurian granted a compulsory license to Natco on March 9, 2012. Bayer filed an appeal against this order before the IPAB but it was dismissed [25].

\section{Analysis of Indian IP Infringement Cases}

The number of patent infringement court cases has increased with the number of patent applications. Satoshi Ogawa, a patent lawyer, reported one patent infringement court case in 1995, which rose to an average of 15 cases per year between 2009 and 2012 [26]. [NOTE 1]

Prathiba M. Singh, Senior Advocate of the Delhi High Court, conducted an analysis in 2014 on IP-related litigation cases and concluded that Indian courts, in many cases, admitted patent infringements by Indian companies and provided "rescues" for innovator companies (foreign capital companies) [27].

Singh reviewed 2,157 IP cases at High Courts between 1995 and 2014 and found that IP holders won in 1,433 cases $(66.4 \%)$. She then extracted 595 cases in which foreign capital companies engaged and found IP holders won in 387 cases $(64.9 \%)$. Based on the analysis, she concluded that, regardless of the nationality of IP holders, they won two-thirds of IP cases in India [27]. [NOTE 2]

Table 4 Results of IP cases in India: IP owners vs. non-owners

\begin{tabular}{|l|r|}
\hline Total cases reported 1995 2005 (May) & 2157 \\
\hline In favor of IP owners & 1433 \\
\hline Against IP owners & 724 \\
\hline Total cases involving foreign companies & 595 \\
\hline Cases in favor of foreign companies & 387 \\
\hline Cases against foreign companies & 209 \\
\hline
\end{tabular}

Source: Singh: Breaking the Anti-IP Myth. Managing Intellectual Property (Sept. 1, 2014) 


\section{Discussion}

As previously mentioned, the numbers of both IP-related applications and grantings in India have increased over the past decade.

However, most IP applications in India are actually occupied by trademarks. The ratio of patents among the total IP applications is only 13\% (see Figure 5).

In fact, most of the cases Singh analyzed were nonpatent cases.

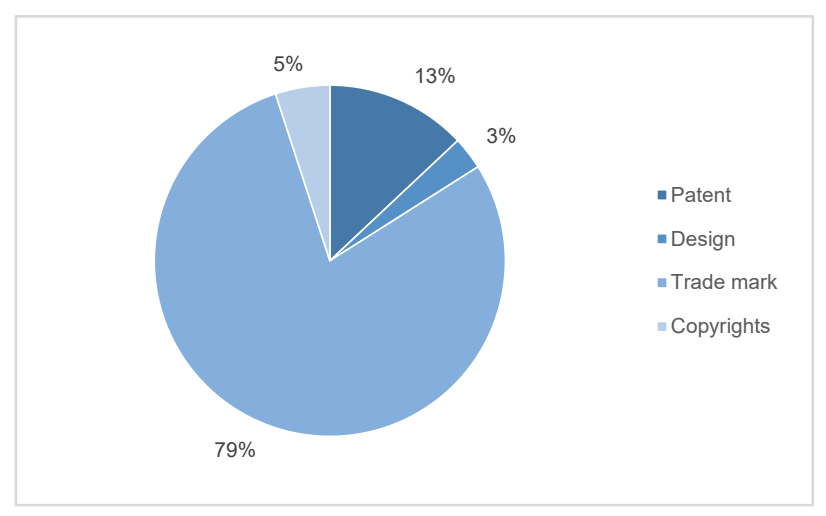

Figure 5 IP applications by category

Source: Indian Patent Office Annual Report FY2014

JETRO compiled the number of IP infringement cases at the Delhi High Court and Mumbai High Court between January 2013 and June 2015 and divided them by category. As a result, patent cases occupied merely 5\% (see Figure 6). [NOTE 3]

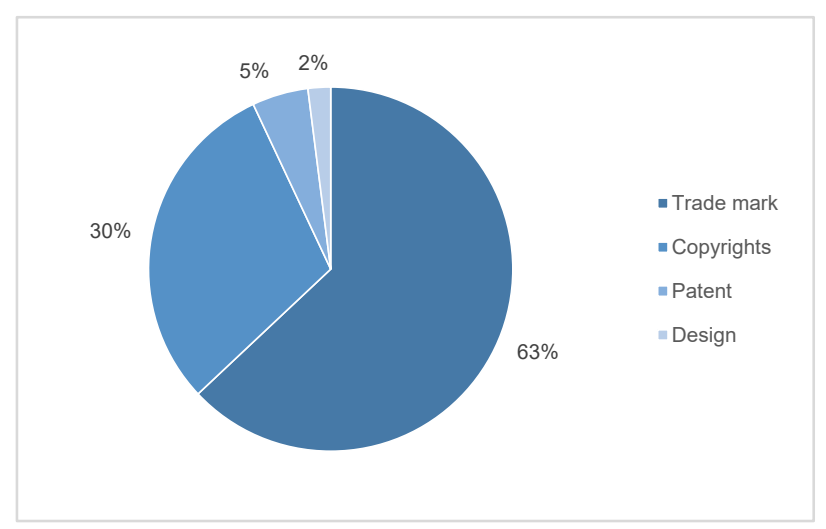

Figure 6 Number of court cases by category Source: JETRO New Delhi IP Division

Although the number of patent infringement cases is lower compared to that of trademark cases, Ogawa points out that it has been increasing [26].

In a seminar held in Tokyo in June 2015, Singh discussed seven patent litigation cases in which foreign pharmaceutical companies won an injunction against Indian generic makers [27].
Table 5 Patent litigation cases in which foreign pharmaceutical companies won an injunction

\begin{tabular}{|c|c|c|c|c|}
\hline medicine & $\begin{array}{c}\text { Plaintiff } \\
\text { (foreign firm) }\end{array}$ & $\begin{array}{c}\text { Defendant } \\
\text { (Indian firms) }\end{array}$ & date & Judgement \\
\hline Vildagliptin (Galvus) & Novartis & Ranbaxy & Sep-14 & a temporary injuction \\
\hline Dasatinib & BMS & BDR Pharma & Jul-15 & a temporary injunction \\
\hline Sitagliptin (Januvia) & MSD & Glenmark & Mar-15 & an injunction \\
\hline Linezolid & Symed & Glenmark \& others & Jan-15 & an injuction \\
\hline Suitinib & Pfizer \& Sugen & Cipla & Apr-13 & an injunction \\
\hline Indacaterol (Onbrez) & Novartis & Cipla & Jan-15 & a temporary injunction \\
\hline Sofosbuvir (Sovaldi) & Gilead & several & Jan-15 & a temporary injunction \\
\hline
\end{tabular}

Source: Singh: Indian IPR Revolution. Presentation material at JETRO Seminar (June 2015), 45-46

$\mathrm{K} \& \mathrm{~S}$, a business consultancy firm in India, indicated that foreign capital companies recently won injunctions in up to $80 \%$ of the IP litigation cases held in the Delhi High Court. [NOTE 4]

However, Indian courts do not release all the information about court cases; therefore, it is difficult to determine whether the number of IP cases in which foreign capital firms won has been increasing recently.

The pharmaceutical industry, one of the technologyoriented industries, has to spend huge R\&D money and has to devote a long development period for new drug development. The industry needs to collect the investment money for a new drug development after the new drug launches. The protection of IPR holds a key for the industry. This study found recent new trend that foreign companies win an injunction in patent infringement cases. It is good news for the foreign pharmaceutical companies which tried to explore the Indian market. The result of this study also may give implications for other technologyoriented industries which consider exploring new markets including the Indian market.

\section{Conclusion}

Advanced countries and foreign pharmaceutical companies believe that IP enforcement is quite weak in India because of a recent landmark lawsuit and issuance of a compulsory license.

However, a recent study carried out by Indian lawyer Singh showed that in approximately two-thirds of the IP cases at Indian High Courts, judges granted favorable judgments for IP holders regardless of the nationalities of the defendants and plaintiffs.

An Indian business consultant company also said in up to $80 \%$ of the IP litigation cases held in the Delhi High Court, foreign capital companies won injunctions.

If what they said are true, these new trends may encourage foreign enterprises to enter the Indian market more aggressively. Since these days pharmaceutical industries in both developing countries and newly industries companies have been developing rapidly while growth of pharmaceutical markets in advanced countries has been sluggish.

However, India Patent Office data show that most IP applications in India are occupied by trademarks. JETRO data show that most IP infringement cases are also occupied by trademarks. 
From these facts, it might be difficult to conclude whether the number of cases patent holders win has been increasing in India.

In addition, the current Indian court system does not disclose all of the judgments. Under the circumstances, it might be quite difficult to determine whether the number of favorable judgments for IP holders are currently increasing or decreasing.

Some High Courts, such as the Delhi High Court, have introduced e-court systems and have been promoting the digitalization of court documentation. Once such an ecourt system is fully implemented in Indian courts and can release judgment data within a reasonably short time, it might be possible to analyze the judgment tendencies.

\section{Note}

[1] a hearing from Satoshi Ogawa, Lawyer at TMI Associates on Jan. 4, 2016

[2] a hearing from Prathiba M. Singh, Senior Advocate of the Delhi High Court on May 3, 2016

[3] a hearing from officers at JETRO New Delhi, on May 3, 2016

[4] a hearing from Amrish Tiwari, Partner at K\&S partners, on May 5, 2016

\section{References}

[1] India Basic Economic Indicator, JETRO. https://www.jetro.go.jp/world/asia/in/stat_01.html., Accessed on Feb. 28, 2019

[2] India's Strong Economy Continues to Lead Global Growth. IMF India. https://www.imf.org/en/News/Articles/2018/08/07/NA08 0818-India-Strong-Economy-Continues-to-Lead-GlobalGrowth., Accessed on Feb. 28, 2019

[3] At Glance, World Bank India. The World Bank Group, (2019). https://www.worldbank.org/en/country/india., Accessed on Feb. 28, 2019

[4] HR Bhojwani, "Developing Innovative Capacity in India to Meet the Health Needs"Govt. of India (Feb 2005), 7

[5] IBEF Pharmaceuticals. (Dec. 2017), 10

6] IBEF Pharmaceuticals. (Dec. 2017), 13

[7] IBEF Pharmaceuticals. (Dec. 2017), 14

[8] Lifestyle Diseases in India. The Borgen Project, (December 1, 2016). https://borgenproject.org/lifestylediseases-in-india/., Accessed on Feb. 28, 2019

[9] International Diabetes Federation website: http://www.idf.org/membership/sea/india., Accessed on Feb. 28, 2019
[10] K. Minato: Indian Pharmaceutical IndustryBackground for Rapid Development and Changes after TRIPS Agreement. In K. Kubo (ed.): Japanese Generic Market and Chinese and Indian Pharmaceutical Industries (IDE-JETRO, 2007), 31

[11] The Indian Pharmaceutical Market-Leading Domestic Companies. GMR Data, (2015), 46

[12] History of Indian Patent System. India Patent Office website: http://www.ipindia.nic.in/history-of-indianpatent-system.htm., Accessed on Feb. 28, 2019.

[13] WTO website: Frequently Asked Questions About TRIPS.

https://www.wto.org/english/tratop_e/trips_e/tripfq_e.ht m., Accessed on Feb. 28, 2019

[14] WIPO website: The Patents (Amendment) Act. (2005), No. 15 of 2005 (India), Accessed on Feb. 28, 2019 [15] Society of Indian Law Firms website: http://www.silf.org.in/16/indian-judicial-system.htm, Accessed on Feb. 28, 2019

[16] Indian Court System website: http://indiancourts.nic.in/index.html., Accessed on Feb. 28,2019

[17] A. Imaura: The Current Status of IP Cases in India. Joho Kanri, 57(12) (2014), 924-927.

[18] Indian Patent Office Annual Reports 1993 2014

[19] India: Number of Patent Applications Submitted in India from 1999-2016

[20] India: Number of Patent Approvals Granted in India from 1999-2016

[21] Y. Mitsumori: Revision of Indian Patent Law and Outlook of Pharmaceutical Industry. Iyaku Keizaisha, (Feb. 2015)

[22] Supreme Court Judgement on April 1, 2003. http://judis.nic.in/supremecourt/imgs1.aspx?filename $=40$ 212., Accessed on Feb. 28, 2019

[23] Madras Court Judgement on Aug. 6, 2007. https://indiankanoon.org/doc/266062/., Accessed on Feb. 28,2019

[24] Intellectual Property Appellate Board Judgement on June 29, 2009.

http://www.lawyerscollective.org/files/novartis/IIIIPAB/ Novartis\%20AG\%20v.\%20UoI\%20and\%20others\%20[I PAB\%20order].pdf., Accessed on Feb. 28, 2019

[25] K. Kubo: An Analysis on Compulsory License Issued on Medical Patent. IDE-JETRO website, (July 2012).

http://www.ide.go.jp/Japanese/Publish/Download/Overs eas_report/1207_kubo.html., Accessed on Feb. 28, 2019

[26] S. Ogawa: The Current Status of IP Practice and Issues in India. Jurist, 1485 (Oct. 2015), 59

[27] P. M. Singh: Breaking the Anti-IP Myth. Managing Intellectual Property, (Sept. 1, 2014) 